\title{
The performance of income-generating projects supported by the Botswana national literacy programme
}

\author{
J Maryann Green* \& Antoinette Motiki
}

\begin{abstract}
OPSOMMING
Die doel van hierdie navorsing was om die onderliggende redes vir die sukses of mislukking van die Botswana National Literacy Programme (BNLP) se inkomste genererende projekte te ondersoek met betrekking tot hoofsaaklik die bestuur van die projekte. Fokusgroepbesprekings is gebruik. Tien werkende en tien mislukte projekte is gekies om deel te neem in hierdie studie. Die projekte is uit die suidelike, suidoostelike en noordelike areas van Botswana getrek. Die resultate het getoon dat wanbestuur, die afwesigheid van uitvoerbaarheidsondersoeke en die generering van te min inkomste die hoof redes was vir die mislukking van BNLP ondersteunde projekte. Al die projekte het genoeg begin-kapitaal gehad. Die projekte wat deur een persoon bestuur is, het 'n groter kans op sukses gehad as die wat deur komitees bestuur is.
\end{abstract}

- Professor JM Green

University of KwaZulu-Natal

Email: green@ukzn.ac.za

* Corresponding author

- Mrs A Motiki

Department of Non-Formal Education

\section{INTRODUCTION}

The Botswana National Literacy Programme (BNLP) was officially launched in 1981 as a major adult literacy initiative. Literacy was in this case defined as; reading, writing and calculating. However, experience over the years of implementation showed that the provision of the $3 R$ s is not enough and literacy needs to be functional in order to be useful to the learners in their daily lives (Wagner 2000:128). Income generating projects were therefore introduced in the National literacy programme as a way of making literacy functional.

The National Literacy programme is offered throughout Botswana by the Department of Non Formal Education's six regional adult education offices. In every regional office, there are regional trainers whose duties include among other things administration, supervision and coordination of literacy activities including income generating activities (Mothusi,1998:123). BNLP projects are introduced by trainers to an area, while a local leader (Literacy Group Leader - LGL) is appointed, paid and trained to teach and help the group. All projects operate in the informal sector with those closest to Gabarone getting the most attention.

It was realized however that many of the BNLPsupported income generating projects failed in spite of them being the recommended approach for functional literacy (Oxenham et al 2002:13). In 1990 the Home Economics programme was evaluated by Social Impact Assessment and Policy Analysis Corporation (SIAPAC) - Africa. Though the content was seen to be well illustrated, there were some deficiencies identified such as the exclusion of many production skills and business skills required by participants to effectively run income generating projects; for example, agriculture-related production skills, marketing and business management among others. The subsequent UNESCO Institute for Education (UIE) evaluation of literacy in Botswana (UIE 2004:13) also identified that adults do not just want to learn the 3Rs but rather learn to use the skills in their daily lives. Adult learners have high expectations for a better life and improved standard of living. To address the learners' needs and to facilitate the functional literacy approach, Home Economics was incorporated into the BNLP in order to link literacy with functional skills and entrepreneurship training became part of that. After acquiring some Home Economics skills, it was hoped that some participants would be motivated to embark on income generating projects.

As a result of these deficiencies, and also as a result of the UIE (2004:40) evaluation, the Home Economics 
programme itself was subsequently extended to include skills useful to start or improve business such as agriculture related production skills; business management including record keeping; marketing including costing and pricing. After training, participants are encouraged to embark on income generating projects which were mostly run by groups (UIE 2004:13). This study therefore aimed at investigating the performance of the income generating projects supported by the BNLP.

\section{AIMS AND OBJECTIVES OF THE STUDY}

The aim of this study was to investigate the performance of income-generating projects supported by the Botswana National Literacy Programme in order to identify contributing factors and constraints towards their sustainability, success or failure.

Accordingly, the following questions were investigated.

A What are the personal contributory factors towards the success or failure of income generating projects in relation to projects meeting personal objectives, group dynamics, economic growth and members' commitment?

B To what extent do the literacy skills learnt in literacy classes contribute to the success and failure of income generating projects?

C What are the underlying business reasons for success and failure of income generating projects with regard to: business management in terms of mismanagement, record keeping, having a constitution and following it, conducting meetings and having office bearers, conducting feasibility studies to ensure availability of the market, correct pricing, promotion, product and place of sale?

D Are there financial resources available to support the BNLP income generating projects?

E What are the underlying reasons for success and failures of income generating projects with regard to ongoing support by BNLP trainers?

\section{FACTORS INFLUENCING THE SUCCESS AND FAILURE OF INCOME GENERATING PROJECTS}

The Botswana income generating success rate has been estimated at 20 percent (Zeleam et al 2004:18). Several studies revealed this to be due to sufficient business management, adequate literacy, good marketing and production skills (Rogers et al 1999:49). However, many studies in Botswana (Social Impact Assessment and Policy Analysis Corporation (SIAPAC)-Africa 1990:86; Mutava \& Mutanyatta 1998:42; UIE 2004:7) have shown that the greatest cause of failure in small businesses is due to mismanagement. Similarly, in Swaziland Mulu-Mutuku (2001) reported that lack of business management skills is a problem that exists within income generating projects. Managerial skills are needed in order to keep income generating projects running. These include financial management, stock control, personnel management as well as record keeping (Charlton 2001:109).

Most of the BNLP income-generating projects are group projects and in most cases only the manager is trained in business management (UIE 2004:53). However as in the case of a study conducted in Kenya by Buckley (1998), the managers lacked transparency. They kept the books to themselves and did not let other members have access to them in order to monitor the finances. This led to great distrust within the groups and caused group disputes. Regular and transparent audits are crucial for group success as they maintain the group's trust in the managers. The fact that managers lacked transparency makes it difficult for project members to gauge real profitability (Catherine 1998). Wickham (1998:40) mentioned that members became dissatisfied when their personal expectations (eg profit making, social support in the group, community recognition) were not fulfilled and they dropped out of projects.

While illiteracy does not pose an impenetrable barrier to production, it does place serious constraints on the success of income generating projects. Illiteracy often limits effective management, record keeping, identification and expansion of markets, acquisition of supplies and related factors central to the growth of projects (Mulu-Mutuku 2001:14). Because of this the teaching of entrepreneurial skills should be accompanied by literacy lessons so that entrepreneurs have both literacy skills (3Rs) and are able to use the necessary skills in the management of their projects especially in reading and keeping records. Rogers et al (1999:67) found that most literacy programmes teach limited production skills and very few business skills.

One of the major problems that contribute to the failure of income generating projects is insufficient market research (Agar 1999). Small businesses usually lack the means to do market research but they should rather concentrate on conducting a feasibility study which will help them find out about their customers (International Labour Organisation (ILO) 1998:5). Knowing about customers is important for both beginning and existing businesses. If the business is not at the beginning stage, it might already have customers, even if they are few. It is worthwhile understanding current customers better and might reveal a group of people for whom the business can do something superior (Mungai 2008:27; Dawson 2003).

In addition, lack of marketing knowledge was identified as a constraint for small businesses. Here the four "Ps" in the marketing mix play a major role. Agar (1999) and Charlton (2001:67) suggested that for income generating projects to get their marketing mix right, they should:

- Look at their target customers and tailor the product or service to suit them.

- $\quad$ Calculate the price which customers will pay and yet still make a profit.

- $\quad$ Plan where the best place will be to make and sell their product or service.

- $\quad$ Examine which methods of promotion will best inform and attract customers.

In addition, quality is important to keep customers satisfied (Motlatla 2003:386). Dawson (2003) identified the fact that many such income generating projects are operated by women "trapped in low value, 
saturated local markets" such as sewing, baking/ cooking and knitting. In order to make a success, women need to add value to what they produce through upgrading their designs, improving their quality or upgrading their customer care (Dawson 2003; Agar 1999).

Failure of income generating projects has often been linked with lack of finance to start or expand (Ngcobo 2003:4). In South Africa, for instance, in a study conducted by Chandra et al (2001:47), finance featured as a constraint to the sustainability of income generating projects. Similarly a task force appointed by the former Botswana Ministry of Commerce and Industry (1998:12) noted some of the problems faced by the Botswana small businesses. Lack of finance was identified as one of the problems. The Gemini report (1992 cited by Mead 1994 in Botswana Ministry of Commerce and Industry 1998:12) states as follows; " $53 \%$ of micro small business reported lack of finance was a problem at start up, and $24 \%$ of those that experienced growth reported that lack of finance was a problem at growth spurt"

\section{METHODOLOGY}

\section{Selection of the respondent groups}

All the projects within the three selected regions of Botswana (southern, south central and northern regions) served as the population for this study. These regions were chosen as they were best served by the BNLP. Criteria for selection were that the projects had to produce their own products or provide a service (not retailing); they marketed and sold their own products themselves, and thirdly represented all the types of projects supported by BNLP. A total of 40 income generating projects were identified as meeting the criteria. Sample selection was by stratified random sampling according to business type, producing 10 each of operating and non-operating projects. See Table 1. Most members $67.2 \%(n=44)$ of operating groups and $58.4 \% \quad(n=45)$ for non-operating groups participated in the study. The researcher conducted 17 focus group discussions and three interviews with the single person project members in accordance with recommendations from Schurink (2003:306) and Bouma (1997:179). The BNLP trainers arranged for the groups to meet, but were not present.

\section{Gathering and analysis of data}

Qualitative strategies were employed with each of the groups themselves using focus group discussions and observations with operating and non operating project members. The discussion guide was pretested for clarity and validity with two similar groups that did not participate further in the study.

The BNLP trainers organized the group meetings for the researcher in their areas of operation because they knew where to find the participants. Once a meeting was arranged at the usual place of production, the role of the researcher became critical since she provided clear explanations in the local language of the purpose of the discussion, helped people feel at ease, and facilitated interaction between group members. To ensure that the participants felt at ease an ice-breaking exercise was given. The participants were asked to draw a cartoon or picture of the best experience they had had in their project and then share their work with the group.

The role of the researcher was to facilitate, not dominate discussion (Macmillan \& Schumacher, 2001:14). She encouraged the participation of everyone by using prompting questions ("probes") to elicit expansion on interesting subtopics, such as "Give us an example of," "Tell us more about that," or "Can someone summarize what we've been saying" were given. The researcher did not ask closed-ended, yes-no questions. As participants asked questions from each other, new avenues of exploration were opened. In discussions, multiple meanings were revealed as different discussants interpreted topics of discussions in different ways. Finally, there was someone engaged in taking notes and recording the conversation of the groups as deemed necessary by writers such as Bouma (1997:179). These were used to establish the trustworthiness of the responses and discussions through inspection by both the researcher and the note taker.

The discussion points were selected in accordance with the suggestions from literature as to identify what aspects promoted success or failure of these income generating projects. Therefore data collected included some personal demographics, project information, literacy responses, and their experience of business management and marketing practices. These included individual experiences of their projects relating to their personal objectives (making money), group dynamics, economic growth and members' commitment while their business practices included discussion about their record keeping, use of constitution, conducting meetings, electing committees. Marketing practices included discussion about conducting feasibility studies and their pricing, promotion, production and places of sale. Financial issues were discussed followed by their perceptions regarding progress and success of their projects. Support from trainers was also talked about.

The researcher also employed observation techniques to confirm the responses obtained through the focus group discussions and tested the use of literacy skills and record-keeping as McMillan and Schumacher (2001:28) recommended. An exercise was given to the participants to find out if the literacy skills learnt in class enabled them to record, read and calculate business records. The researcher also looked at the business records where present.

Analysis was conducted through manual inspection of the contents of the discussion points that the researcher had translated into English. They were then coded and analysed using SPSS. Besides averages, frequencies and percentages, the Pearson ChiSquare test of independence was used to compare the association or correlation between two variables operating and non-operating projects and the aspect 
TABLE 1: POPULATION OF PROJECTS AND NUMBER SAMPLED FROM EACH STRATUM

\begin{tabular}{|c|c|c|c|c|c|c|}
\hline Type of project & $\begin{array}{l}\text { Population of } \\
\text { operating projects } \\
(\mathrm{N}=20)\end{array}$ & $\begin{array}{l}\text { Population of non- } \\
\text { operating projects } \\
\qquad(\mathrm{N}=20)\end{array}$ & $\begin{array}{c}\text { Total } \\
\text { population }\end{array}$ & $\begin{array}{l}\text { Sample operating } \\
\text { projects }(n=10)\end{array}$ & $\begin{array}{l}\text { Sample of non- } \\
\text { operating projects } \\
(n=10)\end{array}$ & $\begin{array}{c}\text { Total } \\
\text { sample }\end{array}$ \\
\hline Sewing & 4 & 8 & 12 & 1 & 4 & 5 \\
\hline Baking & 3 & 8 & 11 & 1 & 4 & 5 \\
\hline Poultry & 3 & 4 & 7 & 1 & 2 & 3 \\
\hline Candle and floor polish & 2 & 0 & 2 & 1 & 0 & 1 \\
\hline Gardening & 2 & 0 & 2 & 1 & 0 & 1 \\
\hline Screen printing & 2 & 0 & 2 & 1 & 0 & 1 \\
\hline Piggery & 1 & 0 & 1 & 1 & 0 & 1 \\
\hline Shoe making and repairs & 1 & 0 & 1 & 1 & 0 & 1 \\
\hline Day care centre & 1 & 0 & 1 & 1 & 0 & 1 \\
\hline Bee keeping & 1 & 0 & 1 & 1 & 0 & 1 \\
\hline Total & 20 & 20 & 40 & 10 & 10 & 20 \\
\hline
\end{tabular}

TABLE 2: DEMOGRAPHICS OF THE TWO SETS OF INCOME GENERATING PROJECTS

\begin{tabular}{|l|l|l|}
\hline \multicolumn{1}{|c|}{ Category } & \multicolumn{1}{|c|}{ Non-operating projects } & \multicolumn{1}{c|}{ Operating projects } \\
\hline Sex & $100 \%$ women & $90 \%$ were women (1 male cobbler) \\
\hline Age & $47-55$ years $(\mathrm{n}=45)$ & $36-46$ years $(\mathrm{n}=44)$ \\
\hline Average literacy level & 2.6 primer level & 3.7 primer level \\
(Max 5) & $(\mathrm{n}=45) 60 \%$ in level 2 & $(\mathrm{n}=44)$ 40\% in level 3 and 5 each \\
\hline Project types & 4 sewing & 1 sewing \\
& 4 baking & 1 baking \\
& 2 poultry & 1 poultry \\
& & 1 candle and floor polish \\
& & 1 gardening \\
& & 1 screen printing \\
& & 1 piggery \\
& & 1 shoe making and repairs \\
& & 1 day care centre \\
& & 1 bee keeping \\
\hline
\end{tabular}

at hand.

\section{Description of the respondents/groups}

A total of twenty income-generating projects supported by the BNLP formed the sample for the study. All the selected projects responded positively. A total of 89 people participated. Amongst the operating projects, two were operated by one person each (sewing and cobbling) while the remaining eight were operated by groups (baking, poultry, candle making, gardening, screen printing, piggery, day care centre and bee keeping). With the projects that were no longer operating, one person had operated one (sewing) while groups had operated the remaining nine (three sewing, four baking, two poultry). All of the members of the non-operating groups were women and their businesses operated in traditional women's arenas and less dynamic markets. The operating businesses included one man who operated on his own (shoe repair). See Table 2

- $\quad$ In the non-operating projects, there were 45 women with an average age of 51 (range 4755 ) years while the average age for operating groups with 44 people was 41 (range 36-46) years. A Chi-Square test revealed that the operating groups were significantly younger $(p=0.002)$. This was unexpected and its impact was not investigated.

Most of the participants within the non-operating pro- jects were in the lower literacy levels, that is, $60 \%$ $(n=27)$ in primer 2 and $30 \%(n=14)$ in primer 3 which is equivalent of year 1 and 2 of primary school with $10 \%(n=4)$ in Primer 5; while $90 \%(n=40)$ of the members in the operating projects were in the upper primers (3-5) which are equivalent to year 4-6 of primary school with $10 \%(n=4)$ in primer 1 . Because of the overlap of levels, this difference was not significant $(p=0.041$ from a Chi-Square test).

Ten different types of business fell within the sample: bakery, bee-keeping, candle-making, day care centre, gardening, piggery, poultry, screen printing, sewing, and lastly shoe making and repairs. It should be noted that the projects that were no longer operating were those of baking, sewing and poultry (these were also the most common types of business in the BNLP supported projects). See Table 2.

\section{RESULTS}

Personal objectives, group dynamics, economic growth, and members' commitment

This section will discuss the underlying reasons for success or failure of the businesses with regard to personal objectives, group dynamics, economic growth, and members' commitment.

Personal objectives Participants in the operating projects interpreted personal objectives as earning money, practising their literacy and building social 
networks. The main reasons given for dropping out of the non-operating projects was because of lack of income growth and group disputes leading to poor socializing. The operating groups added that participating in the projects allowed them to escape from dreary housework. (See Table 3.)

Group dynamics (disputes) Disputes were a most serious cause of non-operation and the nonoperating groups blamed this aspect for their failure. A Chi-Square test reflected a significant correlation between the status of the projects and the presence of group disputes. $(p=0.0000)$ The group approach to income generating activities was thus not encouraging success due to mistrust among members and non transparency of office bearers. (See Table 3.)

Economic growth Lack of economic growth was cited by both groups as not being enough, and the Chi-Square results reflect no significant difference between the non-operating and operating groups $(p=0.047)$. Yet the single owner projects earned substantially more than any of the group projects. The results were also influenced by the poor condition of the various technologies used. There had been virtually no savings for repairs, and over time the nonoperational projects showed a decline in monthly sales. Only the day care centre earned more per person (P400-500) than any of the other projects while both the shoe repairer and the single sewer earned P300-400 per month. The results also showed that candle making (10 members) and piggery (9 members) projects had members earning P200-300 monthly because of the lack of competition for their products. The remaining groups earned less than this per member. (See Table 3.)

Members' commitment There was a significant difference in commitment level (Chi-Square test: $p=0.003$ ) between the status of projects. This was generally ascribed to the choice of business being made by trainers (and not members) and that, in non- operating groups, most decision making was done by the LGLs whom members did not trust. Also the meagre opportunities for participation were identified as a cause of lack of commitment with no sense of belonging. (See Table 3.)

\section{Literacy skills}

The results relating to the underlying reasons for success or failure of the businesses with regard to literacy training revealed that all $(n=89)$ the participants' perception of the importance of acquiring reading, writing and numeracy skills were that:

- $\quad$ Reading and counting are essential in business.

- $\quad$ Most of the skills necessary for running a business require basic knowledge, much of which is difficult to obtain unless people are literate and numerate.

- $\quad$ People must be able to keep records and communicate effectively.

During the reading, writing and calculating exercise given to the project members, the researcher observed that in both operating and non-operating projects, even those members that could read and write $(70 \%)$ had difficulty in calculating. Only members who were doing primer levels 3-5 could read the mothertongue exercise given to them but even among these, very few people understood what they were reading and they also had difficulty with the calculations they were required to do. Never-the-less even this low level of literacy could benefit the operating businesses.

It was also realized that $90 \%$ of all groups (18 of the 20) depended on their LGLs when it came to tasks that required them to read, write and calculate especially business records. Oxenham et al (2002:8) identified that lack of record keeping skills in income generating projects was a constraint. It was agreed by all that entrepreneurship training had been included in

TABLE 3: PERSONAL FACTORS CONTRIBUTING TO SUCCESS OF PROJECTS ( $\mathrm{N}=\mathbf{2 0})$

\begin{tabular}{|c|c|c|c|c|}
\hline \multirow{2}{*}{ Project status } & & \multicolumn{2}{|c|}{ Objectives not met } & \multirow{2}{*}{ Total } \\
\hline & & no & yes & \\
\hline Non-operating projects & Count & 2 & 8 & 10 \\
\hline Operating projects & Count & 9 & 1 & 10 \\
\hline \multirow[t]{3}{*}{$x^{2}$ test } & & & & $p=0.002$ \\
\hline & & \multicolumn{2}{|c|}{ Group disputes present } & \multirow{2}{*}{ Total } \\
\hline & & no & yes & \\
\hline Non-operating projects & Count & 1 & 9 & 10 \\
\hline Operating projects & Count & 9 & 1 & 10 \\
\hline \multirow{3}{*}{$x^{2}$ test } & & & & $p=0.000$ \\
\hline & & \multicolumn{2}{|c|}{ Economic growth } & \multirow{2}{*}{ Total } \\
\hline & & no & yes & \\
\hline Non-operating projects & Count & 2 & 8 & 10 \\
\hline Operating projects & Count & 5 & 5 & 10 \\
\hline \multirow[t]{3}{*}{$x^{2}$ test } & & & & $p=0.047$ \\
\hline & & \multicolumn{2}{|c|}{ Lack of commitment } & \multirow{2}{*}{ Total } \\
\hline & & no & yes & \\
\hline Non-operating projects & Count & 0 & 10 & 10 \\
\hline Operating projects & Count & 6 & 4 & 10 \\
\hline$x^{2}$ test & & & & $p=0.003$ \\
\hline
\end{tabular}

The performance of income-generating projects supported by the Botswana national literacy programme 
their classes. This had incorporated business management, marketing and production skills but there was no difference in the value contributed to the businesses. (Chi-Square test: $p=0.060)$. This implied that the training seemed ineffective.

Members reported that literacy learnt in BNLP classes did not link the development of reading, writing and numeracy skills to those needed for business record keeping. Most respondents $(70 \%)$ reported that the lessons given in literacy classes did not have any relevance to income generation projects. The study also revealed that BNLP trainers were perceived to be inadequately trained in business skills and participatory learning/teaching methods.

\section{Business management}

The underlying reasons for sustainability or failure of income generating projects with regard to business management included the following aspects: mismanagement, record keeping, having a constitution and following it, conducting meetings and electing office bearers and following the general marketing principles namely conducting a feasibility study, selecting the correct product, pricing and promoting the product and selecting a place of sale.

Mismanagement The results showed that group disputes about mismanagement and general distrust seemed to be the most serious problem and one of the main factors that contributed to the failure of projects. Ninety percent of the non-operating projects reported to have stopped operating due to mismanagement while no operating groups indicated that they had this problem. A Chi-square analysis showed a significant correlation $(p=0.000)$ between the status of the projects (operating or non-operating) and the extent to which the projects members experienced mismanagement problems or not (Table 4). The group members mentioned mismanagement in relation to abuse by LGLs (facilitators) who took over the management of the projects and chased project members away. LGLs were also seen to have favoured their friends, were not very transparent in managing the projects, used poor record keeping (which was also observed by the researcher), did not follow the group's constitution and worst of all, used the money for personal benefit without accounting for it. Catherine (1998) in her study in Cameroon identified similar problems among the projects that she studied. She saw the use of money from the till without accounting for it as a drawback in the projects as eventually some of the projects ended in bankruptcy.

Record keeping There was no difference found in the keeping of records - yet the researcher observed that only 17 projects kept minutes, a cash book and debtors records. There were no stock and sales records kept at all. Chi-square test showed with $p=0.047$ that record keeping was similar in both nonoperating and operating groups. (See Table 4.)

Constitution Almost all groups (9 non-operating and 8 operating) had a constitution to guide them in running their projects but none of the non-operating groups reported using them while eight of the operating projects did. Use of the constitution was a positive factor in the status of projects (Chi-square result $p=0.000$ ) although the members reported not participating in drawing them up. Some groups blamed the LCLs for keeping them to themselves and they were not familiar with the contents. The constitution was used purely for securing grants and registering with the government. (See Table 4.)

TABLE 4: BUSINESS MANAGEMENT FACTORS CONTRIBUTING TO SUCCESS OF PROJECTS ( $\mathrm{N}=20)$

\begin{tabular}{|c|c|c|c|c|}
\hline & & \multicolumn{2}{|c|}{ Mismanagement? } & \multirow{2}{*}{ Total } \\
\hline & & no & yes & \\
\hline Non-operating projects & Count & 1 & 9 & 10 \\
\hline Operating projects & Count & 10 & 0 & 10 \\
\hline$x^{2}$ test & & & & $p=0.000$ \\
\hline & & \multicolumn{2}{|c|}{ Record keeping present? } & \multirow{2}{*}{ Total } \\
\hline & & no & yes & \\
\hline Non-operating projects & Count & 0 & 10 & 10 \\
\hline Operating projects & Count & 3 & 7 & 10 \\
\hline$x^{2}$ test & & & & $p=0.000$ \\
\hline & & \multicolumn{2}{|c|}{ Using the constitution? } & \multirow{2}{*}{ Total } \\
\hline & & no & yes & \\
\hline Non-operating projects & Count & 10 & 0 & 10 \\
\hline Operating projects & Count & 2 & 8 & 10 \\
\hline$x^{2}$ test & & & & $p=0.000$ \\
\hline & & \multicolumn{2}{|c|}{ Holding regular meetings? } & \multirow{2}{*}{ Total } \\
\hline & & no & yes & \\
\hline Non-operating projects & Count & 8 & 2 & 10 \\
\hline Operating projects & Count & 0 & 10 & $\overline{10}$ \\
\hline$x^{2}$ test & & & & $p=0.000$ \\
\hline & & \multicolumn{2}{|c|}{ Changing office bearers? } & \multirow{2}{*}{ Total } \\
\hline & & no & yes & \\
\hline Non-operating projects & Count & 9 & 1 & 10 \\
\hline Operating projects & Count & 5 & 5 & 10 \\
\hline$x^{2}$ test & & & & $p=0.063$ \\
\hline
\end{tabular}


Meetings and office bearers Eight of the nonoperating groups did not have regular meetings while all the operating groups did. Having regular meetings then did seem to encourage sustainability (Chi-square test $p=0.000$ ). The non-operating groups reported that their meetings were spent on discussing disputes and what the LGLs wanted and were not focused on decisions relating to project progress. (See Table 4.)

Office bearers were generally not rotated by either category of project. Chi-square results showed no difference between non-operating and operating groups $(p=0.063)$. LGLs remained in control and generally appointed their friends as permanent members of the committees. Even $50 \%$ of the operating projects had not changed their office bearers since inception. However, the researcher observed that neither groups operated independently because all project decisions were made by LGLs and a few other members. This meant that when LGLs pulled out from projects, they stopped operating.

Marketing The following section will discuss the findings that looked at the underlying reasons for sustainability or failure of income generating projects with regard to marketing in terms of: conducting feasibility studies, product selection, pricing, promotion, and place of sale.

Feasibility study Most (80\%) of the non-operating projects did not conduct feasibility studies before the commencement of their projects while $80 \%$ of the operating projects did so, albeit simply. From these findings, it could be concluded that one of the contributory factors to the failure of projects could have been lack of conducting a feasibility study before starting the business. A Chi square analysis showed a significant correlation $(p=0.007)$ between the status of the projects (operating or non-operating) and whether the project members conducted a feasibility study or not (Table 5). It is important to conduct a feasibility study before starting business in order to be able to determine if what is produced will be needed by customers, if the customers can afford to pay the price set, if the business will make profit, if the business will be at the right place to be easily reached by customers and the appropriate promotion done. This is taking into consideration the four controllable marketing strategies which ILO (1998:5) sees as very important. A feasibility study is essential for income generating projects because knowing the factors that influence a consumer purchasing decision gives direction as to what products to produce, how to improve the business to satisfy consumer's needs and make a profit. If a feasibility study is not carried out, an income-generating project is more likely to fail because it might be operating in a wrong environment, a wrong type of product produced or a wrong operational strategy might be implemented (Charlton 2001:40).

Product selection Research results indicated that sewing and bakery projects were mostly nonoperating projects. They arrived at the choice of their products through motivation from the success of other businesses selling the same or similar products in the same area (60\%). Mutava and Mutanyatta (1998:46) identified a similar situation in their study. Most of the non-operating projects reported lack of demand for their product as one of the reasons for closure. These groups also mentioned that their potential customers preferred cheaper clothes such as those stocked by Chinese shops. It was observed that the nonoperating projects did not do anything to differentiate their products from their competitors in order to occupy a market niche as recommended by Agar (1999).

TABLE 5: MARKETING FACTORS CONTRIBUTING TO SUCCESS OF PROJECTS ( $\mathbf{N = 2 0 )}$

\begin{tabular}{|c|c|c|c|c|}
\hline \multirow{2}{*}{ Project status } & & \multicolumn{2}{|c|}{ Feasibility study conducted } & \multirow{2}{*}{ Total } \\
\hline & & no & yes & \\
\hline Non-operating projects & Count & 8 & 2 & 10 \\
\hline Operating projects & Count & 2 & 8 & 10 \\
\hline \multirow[t]{3}{*}{$x^{2}$ test } & & & & $p=0.007$ \\
\hline & & \multicolumn{2}{|c|}{ Own product selection } & \multirow{2}{*}{ Total } \\
\hline & & no & yes & \\
\hline Non-operating projects & Count & 6 & 4 & 10 \\
\hline Operating projects & Count & 3 & 7 & 10 \\
\hline \multirow[t]{3}{*}{$x^{2}$ test } & & & & $p=0.025$ \\
\hline & & \multicolumn{2}{|c|}{ Correct pricing of products } & \multirow{2}{*}{ Total } \\
\hline & & no & yes & \\
\hline Non-operating projects & Count & 7 & 3 & 10 \\
\hline Operating projects & Count & 3 & 7 & 10 \\
\hline \multirow[t]{3}{*}{$x^{2}$ test } & & & & $p=0.006$ \\
\hline & & \multicolumn{2}{|c|}{ Promotion at trade fairs } & \multirow{2}{*}{ Total } \\
\hline & & no & yes & \\
\hline Non-operating projects & Count & 7 & 3 & 10 \\
\hline Operating projects & Count & 1 & 9 & 10 \\
\hline \multirow[t]{3}{*}{$x^{2}$ test } & & & & $p=0.006$ \\
\hline & & \multicolumn{2}{|c|}{ Production $=$ place of sale } & \multirow{2}{*}{ Total } \\
\hline & & no & yes & \\
\hline Non-operating projects & Count & 0 & 10 & 10 \\
\hline Operating projects & Count & 2 & 8 & 10 \\
\hline
\end{tabular}

The performance of income-generating projects supported by the Botswana national literacy programme 
Sixty percent of the non-operating groups also mentioned that they produced products that were recommended by their trainers $(60 \%)$. Though it is vital for trainers to assist in the choice of projects, the members felt that it was inappropriate for them as outsiders to decide for the members which projects they should embark on. This has been found to be disempowering and undermining of people's autonomy (Ikelegbe \& Ikelegbe, 2002). The participants tend to know their community needs better and therefore it may have been wiser for them to decide on the types of projects rather than the trainers. Very few nonoperating projects $(30 \%)$ indicated that they arrived at the choice of their products because of customers' needs. Not considering customers needs may have contributed to the failure of the projects. Though the operating projects also reported that they arrived at the choice of their products through motivation from the successful projects $(80 \%)$, they also considered the needs of the customers $(80 \%)$ before embarking on their projects. This latter tendency was an important, but not significant, difference between the nonoperating and operating projects (chi-square result $p=0.025$ ). Agar (1999) found that few income generating projects considered people's needs when selecting types of products to make. (See Table 5.)

Pricing of products Many income-generating projects did not calculate all the costs incurred during manufacturing when pricing products. These research findings indicated that $70 \%$ of the non-operating projects and $30 \%$ of the operating ones calculated only material and paid labour costs when pricing. Lack of including all the costs incurred when pricing could be seen as a contributory factor to the failure of projects. A chi- square analysis showed significant correlation $(p=0.006)$ between the status of the project (operating or non-operating) and if the project members calculated only the material and paid labour costs when pricing (Table 5). Improper pricing resulted in projects that did not make any profits to sustain the business and therefore eventually the businesses went under. Members also lost hope as a result. To be able to price well, they needed to include all the costs incurred to produce a product or service (including transport, equipment and their own time) and ensure that there is profit made at the end of the day (Charlton 2001:109).

Promotion of products Income generating project members made very little attempt to promote their businesses. All the respondents indicated that they depended on promotion by word of mouth. As highlighted by Pattern (2001:16), while word of mouth promotion may help a small business at start-up, this is generally not enough. To truly generate sales, it is necessary to advertise on a larger scale in order to attract customers to a business.

Dawson (2003) in his study found that the use of exhibitions and trade fairs was a good way of promoting income generating projects and their products were often found to be highly effective. This could also be seen to be a contributory factor to the success of the operating projects in this study because $90 \%$ of the groups also indicated that they had promoted their products by exhibiting at trade fairs. A Chi-square analysis showed a significant correlation $(p=0.006)$ between the status of the projects (operating or nonoperating) and if the project members exhibited their products at trade fairs or not. (See Table 5)

Place of sale Members reported that the location of the projects was seen not to be a problem because they could be easily reached by customers. A major problem identified by the researcher however emanated from the fact that those projects that failed were crowded with similar businesses in same locations. Also, generally the place of production was the same as the place of sales and often did not satisfy both requirements adequately. (See Table 5.)

\section{Financial resources}

In spite of literature stating that lack of start-up finances is a major deterrent for success in small businesses (Botswana Ministry of Commerce and Industry, 1998:11), this was not the case here because during the focus group discussions fewer than half of all the respondents (from $30 \%$ of non-operating and $10 \%$ of operating projects) mentioned lack of finance as one of the problems. The groups however mentioned that they were aware of government and NGO funding sources and the operating ones mentioned that they were preparing to apply for additional funding. All except for three operating projects however also reported that they received grants from the government and NGOs to start their projects. This meant that the lack of start-up finance was not a major problem (Botswana Ministry of Commerce and Industry, 1998). All the groups agreed that if the funds they received when they started their projects were managed effectively and every member had put in effort and shown commitment to their work, they would not have had any financial problems.

\section{Support from trainers.}

The lack of support by trainers was identified by members of both sets of projects to be important. They complained that trainers did not visit and support the groups sufficiently after the initial training. Responses stated that visits occurred once in 6 months $(10 \%)$, once a year $(60 \%)$ or even once every 2 years $(30 \%)$. The visits themselves were also seen as unsatisfactory because the trainers did not try to resolve any problems. However, this may also be an indication of dependency which most development practitioners see as hindering project sustainability. A better balance was needed here (Rogers et al, 1999:56,).

\section{CONCLUSIONS AND RECOMMENDATIONS}

The results of this study reflect that causes of failure of the projects were seen to be due to mismanagement by the leaders leading to disputes and a lack of trust, inadequate levels of literacy, and non-existent feasibility studies before the commencement of projects to ensure that the right products are offered to customers at the right price, right place with appropriate promotion. Unexpectedly, almost all the projects received grants to start their projects and therefore 
start up finances were not a problem. Rather the shortage of funds for expansion or ensuring sustainability of projects was felt to be due to mismanagement of those funds by the office bearers and mostly the LGLs.

The projects run by one person (rather than a committee) reflected better performances than those of groups because owners managed their projects and earned better wages than group members. The expectations of members were generally not met, especially those of raising living standards, and attaining satisfactory economic growth. The lack of adequate literacy levels also meant that records were either not kept or could not be understood easily, thus generating a lack of trust.

In order to improve projects, BNLP should select one region for an intensive pilot project designed to improve the performance of income generating projects. Business training skills should be incorporated into the literacy curriculum i.e. when BNLP curriculum developers design a literacy curriculum, they should include a functional skills component e.g. teaching learners key business skills such as simple record keeping, banking, and also required skills necessary to help the group function effectively with democratic decision-making, group dynamics and conflict resolution. In addition, unique products should be encouraged to avoid the competition from similar projects situated close by.

\section{REFERENCES}

AGAR, J. 1999. Marketing for the local market: What does it mean in practice? Small Enterprise Development 20(4):4-15.

BOTSWANA MINISTRY OF COMMERCE AND INDUSTRY. 1998. Industrial Development Policy for Botswana. Gaborone. Government Printers.

BOUMA, D. 1997. The Research Process. Oxford University Press. New York.

BUCKLEY, G. 1998. Application of Sub-Sector analysis: The case of informal sector in Kenya. Small Enterprise Development 9(2):50-56.

CATHERINE, F. 1998. Are women Micro Enterprises Profitable? A case study of Cameroon Women. Small Enterprise Development 9(3):50-55.

CHANDRA ,V, MOORTY, L, NGANOU, J, RAJARATNAM, B \& SCHAEFER, K. 2001. Constraints of growth and employment in South Africa: Report No 2 evidence from small, medium and micro enterprise firm survey. Pretoria. The World Bank. Southern Africa.

CHARLTON, T. 2001. Enterprising Botswana: Starting your business. Gaborone. TNT.

DAWSON, J. 2003. Facilitating Small Producers Access to high Value Markets: Lessons from Four Development Projects. Journal of Micro Finance and Business Development 14:13-25.

IKELEGBE, O \& IKELEGBE, A. 2002. Participation and Low Sustenance: The Problem with the Rural

Development Programme in Nigeria. Journal for Rural Development 21:553-578.

INTERNATIONAL LABOUR ORGANISATION. 1998.

Improve your Business. Harare. ILO

MCMILLAN, J \& SCHUMACHER, S. 2001. Research

in education: A conceptual introduction. London.

Longman

MOTHUSI, G. 1998. Literacy in Botswana: experience from the Botswana National Literacy Programme: The first National Survey in Botswana. Gaborone. Department of Non-formal Education.

MOTLATLA, L. 2003. Introduction to Business Management. Cape Town. Oxford University Press. MULU-MUTUKU, M. 2001. Pastoral Communities and Entrepreneurship Development: Implication for Adult Education. Journal of Adult Education and Development 54:141-148.

MUNGAI, E. 2008 . The role of assets, group management, constraints, benefits and community support to the success of women's groups. A case study of Maphephethe area of KwaZulu Natal. Unpublished thesis. University of Natal. Pietermaritzburg.

MUTAVA, D \& MUTANYATTA, J. 1998. The Need for Post Literacy in Botswana. Gaborone. University of Botswana.

NGCOBO, K. 2003. Divesting and Investing as strategic decisions for small business entrepreneurship. Unpublished thesis. University of Natal. Pietermaritzburg.

OXENHAM, J, DIALO, A, KATAHOIRE, A, MWANGI, A, SALL, O. 2002. Skills and Literacy training for better livelihood. Adult Education and Development: (58): 8-43.

PATTERN, D. 2001. Successful Marketing for Small Business. London. British Library Cataloging in Public data.

ROGERS, A, MADDOX, B, MILLICAN, J, JONES, K, PAPPEN, U \& ROBBIN-PANT, A. 1999. Redefining post literacy in a changing world. London. Department for International Development.

SCHURINK, E. 2003. The methodology of unstructured face-to-face interviewing. In De Vos, A. 2003. Research at Grass Roots. Pretoria. Van Schaik. Social Impact Assessment and Policy Analysis Corporation (SIAPAC)-Africa. 1990. An Evaluation of Botswana Home Economics Programmes. Gabarone. Government Printers.

UNESCO INSTITUTE FOR EDUCATION (UIE). 2004. Sharpening the Focus: Evaluation of the Botswana National Literacy Programme. Hamburg. UNESCO Institute of Education.

WAGNER, D. 2000. Literacy and Adult Education. Journal for Adult Education and Development 55:129141

WICKHAM, P. 1998. Strategic Enterprise. London. Pitman Publishing.

ZELEAM, T, TEMTIME, T, \& PANSIRI, J. 2004. Small business critical success/failure factors in developing economies: Some evidence from Botswana. Gaborone. University of Botswana. 